\title{
Juru Sembelih Halal Berbasis Pada Walisongo Halal Research Center (WHRC)
}

\author{
Mohamad Solek \\ Universitas Islam Negeri Walisongo \\ Email : mohamadsolek@ymail.com
}

\begin{abstract}
In everyday life, we can't escape from eating meat, but sometimes we often question about the status of halalness, that is whether it meets the criteria of halal slaughter according syara' or not yet. The effort to realize the halal slaughter is to conduct Halal Slaughter Training marching at the Walisongo Research Center for students of Walisongo State Islamic University of Semarang. The halal slaughterhouses training activities are designed in the form of intensive and continuous training accompanied by expert of the Food and Cosmetics Review Institute (LP POM) of Central Java MUI, experts of the Livestock and Animal Health Service (DISNAKKESWAN) and Walisongo Halal Research Centre (WHRC). The results of this dedication in the implementation of the halal slaughterer training is that students are able to understand the halal slaughtering way (according to Syara' and MUI Standard) and be able to practice a professional halal slaughterer, while the sustainability of this training is Student/graduate of Walisongo State Islamic University of Semarang as "Profesional Halal Slaughterer" in their regions.
\end{abstract}

Abstrak: Dalam kehidupan sehari-hari kita tidak bisa lepas dari mengonsumsi daging, namun terkadang kita sering mempertanyakan tentang status kehalalan tersebut yaitu apakah sudah memenuhi kriteria penyembelihan halal sesuai syara' atau belum. Upaya untuk mewujudkan penyembelihan halal tersebut adalah dengan mengadakan Pelatihan Juru Sembelih Halal berbasis pada Walisongo Halal Research Center (WHRC) bagi mahasiswa UIN Walisongo Semarang. Kegiatan pelatihan juru sembelih halal tersebut didesain dalam bentuk pelatihan yang dilakukan secara intensif dan kontinu dengan didampingi oleh tenaga ahli Lembaga Pengkajian Pangan Obat-obatan dan Makanan (LPPOM) MUI Jawa Tengah, tenaga ahli Dinas Peternakan dan Kesehatan Hewan (DISNAKKESWAN) dan tenaga ahli Walisongo Halal Research Center (WHRC). Hasil kinerja pengabdian dalam pelaksanaan pelatihan juru sembelih halal yaitu Mahasiswa mampu memahami cara menyembelih yang halal (sesuai Syara' dan Standar MUI) dan mampu mempraktekkan menjadi juru sembelih yang halal profesional, adapun keberlanjutan pelatihan ini adalah Mahasiswa/Alumni UIN Walisongo Semarang sebagai "JuruSembelih Halal yang Profesional" di daerah asalnya masing-masing.

Kata Kunci: sembelih, hewan ternak, halal. 


\section{PENDAHULUAN}

Penyembelihan binatang tidak sama dengan mematikan. Mematikan binatang dapat dilakukan dengan berbagai cara, seperti dipukul, disabet dengan senjata, disiram dengan air panas atau dibakar. Namun cara-cara tersebut tidak dicontohkan oleh Rasulullah SAW dan termasuk tindakan kejam. Adapun yang dimaksud penyembelihan binatang ialah memutus jalan makan, minum, nafas dan urat nadi pada leher binatang yang disembelih dengan menggunakan pisau, pedang, atau alat lain yang tajam sesuai dengan ketentuan syara`.

Maka dari itu dalam melakukan penyembelihan harus dilakukan dengan baik dan benar. Sebagaimana sabda Rasulullah SAW: "Sesunggubnya Allah menetapkan supaya berbuat baik terhadap segala sesuatu. Apabila kamu membunuh, bunublah dengan baik. Apabila kamu hendak menyembelih, sembelihlah dengan baik dan hendaklah mempertajam pisaunya dan memberikan kesenangan terhadap binatang yang disembelih. (HR. Muslim).

Sebagai orang yang beriman, kita tidak boleh menyembelih binatang secara sembarangan. Kita harus mengikuti tata cara dan ketentuan-ketentuan syarat dalam menyembelih binatang. Adapun mengenai penyembelihan hewan sebenarnya sudah diatur dalam Fatwa MUI Nomor 12 Tahun 2009 tentang Standar Sertifikasi Penyembelihan Halal.

Pelatihan penyembelihan diperlukan sebagai wujud kepedulian dan pengembangan ilmu pengetahuan, serta usaha mewujudkan penyembelihan halal sesuai dengan Syara' dan Fatwa MUI Nomor 12 Tahun 2009. Adapun isu dan fokus pengabdian ini adalah sebagai berikut; pertama, minimnya pengetahuan mahasiswa UIN Walisongo Semarang tentang penyembelihan halal. Kedua, minimnya sarana dan prasarana penyembelihan hewan di UIN Walisongo Semarang. Dan ketiga, besarnya minat mahasiswa UIN Walisongo Semarang untuk menjadi juru sembelih.

Ada dua alasan utama pemilihan mahasiswa UIN Walisongo Semarang sebagai subyek dampingan dalam karya pengabdian. Pertama, banyaknya mahasiswa yang memiliki potensi menjadi juru sembelih halal, namun karena minimnya pengetahuan dan pembinaan menjadikan potensi tersebut kurang terasah. Kedua, kebanyakan mahasiswa UIN Walisongo Semarang berasal dari berbagai daerah, sehingga melalui kegiatan pelatihan juru sembelih halal ini diharapkan mampu menyalurkan dan menerapkannya di daerah masing-masing. Sehingga pelatihan juru sembelih halal ini diharapan menjadi salah satu penunjang ekonomi kreatif di masyarakat. Tulisan ini menguraikan bagaimana praktek pelatihan penyembihan halal dan bagaimana memilih hewan yang halal.

Kegiatan pelatihan juru sembelih halal di UIN Walisongo Semarang dilakukan secara intensif. Adapun hasil yang diharapkan dari pendampingan ini adalah sebagai berikut:

1. Meningkatkan keterampilan mahasiswa sebagai juru sembelih profesional 
2. Mendapatkan ladang usaha baru dalam menanggulangi pengangguran

3. Memunculkan kreativitas mahasiswa sebagai penunjang ekonomi kreatif di masyarakat

4. Menjadikan UIN Walisongo sebagai pusat pemotongan hewan sesuai standar LPPOM MUI dan Dinas Peternakan dan Kesehatan Hewan

5. Peserta pelatihan dapat mengajarkan kemampuan penyembelihan hewan kepada masyarakat sebagai manifestasi dari penerapan ilmu pengetahuan dan pengembangan diri untuk mewujudkan ekonomi kreatif masyarakat.

\section{STRATEGI DAN METODE YANG DILAKUKAN}

Kegiatan pelatihan juru sembelih halal ini didesain dalam bentuk pelatihan yang dilakukan secara intensif dan kontinu Sedangkan tahapan dan metode yang digunakan dalam pelatihan tersebut di antaranya; pertama, tahap persiapan. Tahapan ini meliputi;

a. Menyusun tim pelaksana lapangan (panitia penyelenggara)

b. Melakukan sosialisasi kepada mahasiswa UIN Walisongo Semarang

c. Mencari tutor ahli juru sembelih halal

d. Melakukan koordinasi dengan tim pelaksana lapangan

Kedua, tahap pelaksanaan. Tahapan ini merupakan yang utama dari rangkaian pengabdian. Di sini dilaksanakan dan diuraikan terkait hal berikut;

a. Pemaparan teknik juru sembelih halal

b. Pembuatan tempat penyembelihan

c. Pengadaan alat penyembelihan

d. Pelaksanaan penyembelihan

Ketiga, tahap evaluasi, merupakan tahap akhir dari rangkaian pengebadian. Setelah semua rangkaian tahap dijalani, maka langkah terakhir adalah melakukan evaluasi. Evaluasi ini perlu dilakukan supaya kegiatan kedepannya akan lebih baik. Kegiatan ini juga di desain supaya kedepannya dapat dilaksanakan secara berlanjut dengan dana swadaya secara mandiri.

Penelitian berbasis pengabdian ini termasuk dalam penelitian lapangan (field research) yaitu penulis menggunakan ayam sebagai sampel untuk proses penyembelihan halal. Jenis penelitian ini adalah kualitatif, yakni dengan pendekatan deskriptif yang bertujuan untuk mengetahui uraian secara mendalam tentang proses penyembelihan halal berbasis pada Walisongo Halal Research Center (WHRC).

Data penelitian menurut sumbernya digolongkan menjadi dua yaitu data primer dan data sekunder. Data primer dalam penelitian ini adalah proses penyembelihan halal berbasis pada Walisongo Halal Research Center (WHRC). Sedangkan sumber data sekunder yang dijadikan data pendukung yakni literatur yang membahas tentang hewan-hewan yang boleh disembelihdan proses penyembelihan hewan yang halal. 
Data diperoleh melalui tiga upaya berikut; pertama observasi. Teknik observasi merupakan teknik pengumpulan data dengan melalui pengamatan atau praktek secara langsung terhadap obyek yang diteliti. Teknik observasi yang digunakan pada penelitan ini adalah observasi berpartisipasi atau observasi partisipan, artinya peneliti tidak hanya berlaku sebagai pengamat saja melainkan juga mempraktekkan secara langsung proses penyembelihan halal berbasis pada Walisongo Halal Research Center (WHRC).

Kedua, dokumentasi. Metode dokumentasi yaitu mencari data mengenai hal-hal atau variabel yang berupa catatan, transkip, buku, suratkabar, majalah, prasasti, notulen rapat, lengger, agenda, dan lain sebagainya. Jadi peneliti mengumpulkan data-data dari literatur yang membahas mengenai penyembelihan halal..

Ketiga, wawancara. Metode wawancara yaitu mendapatkan informasi dengan cara bertanya langsung kepada responden. Responden di sini adalah Tutor ahli pelatihan juru sembelih halal yaitu dari Lembaga Pengkajian Pangan, Obat-obatan dan Makanan Majelis Ulama Indonesia (LPPOM MUI) Jawa tengah dan Dinas Peternakan dan Kesehatan Hewan (DISNAKKESWAN) Provinsi Jawa Tengah.

Setelah data-data yang dibutuhkan terkumpul, kemudian data-data tersebut diolah dan dianalisis bersamaan dengan proses penyajiannya dengan metode deskriptif-analitik, metode yang akan menggambarkan dan menganalisis objek dalam penelitian. Alasan penggunaan metode ini karena merupakan penelitian lapangan yang menggunakan jenis penelitian kualitatif. Analisis dilakukan dengan mendeskripsikan sekaligus menganalisa bagaimana proses penyembelihan halal berbasis padaWalisongo Halal Research Center (WHRC).

\section{PENYEMBELIHAN HALAL}

Perkembangan ilmu dan teknologi membawa pengaruh di berbagai sektor kehidupan. Mulai dari makanan, cara berbelanja, pakaian dan lain sebagainya. Dalam mengantisipasai hal hal tersebut, ajaran Islam telah siap dalam menghadapinya dengan prinsip-prinsip hukum yang telah ada. Berikut prinsipprinsip mengenai halal-haram yang dikemukakan oleh DR Yusuf Qardhawi dalam karyanya "Halal Haram fil Islam".

Pertama, hukum asal bagi setiap sesuatu adalah mubah. Tidak ada satupun sesuatu yang haram kecuali segelintir yang disebut haram oleh ajaran Islam. Para ulama merumuskan kaidah bahwa setiap sesuatu adalah boleh. Kaidah ini dirumuskan dari beberapa ayat Al-Qur'an, seperti Qur'an Surah AlBaqarah 29, al-Jatsiyah 13, dan Surah Al-Luqman 20. Dengan demikian diketahui bahwa Allah Ta'ala tidak menciptakan semua yang dikaruniakan kepada manusia dalam keadaan haram, kecuali lalu dia mengharamkannya. 
Mengenai kehalalan sesuatu atau keharamannya seperti Rasulullah SAW bersabda yang diriwayatkan oleh al-Hakim yang artinya :

"Apa yang Allah halalkan di dalam KitabNya, maka ia adalah halal. Dan, apa yang Allah haramkan, maka ia adalah haram. Manakala apa yang didiamkan olebNya, maka ia adalah dimaafkan. Oleb itu, terimalah kemaafan dari Allah.Sesunggubnya Allah tidak akan lupa sedikitpun. "Kemudian Rasulullab s.a.w. membaca ayat: "Dan Tuhanmu tidak pelupa."(Maryam: 64). (HR al-Hakim)

Kedua, penentuan halal-haram adalah otoritas Allah. Disebutkan dalam QS. Al-An'am : 119, "Sungguh Allab telab menerangkan kepadamu apa yang Ia haramkan atas kamu". Dengan demikian maka yang menghalalkan dan mengharamkan sesuatu bukanlah penguasa ataupun rahib.

Ketiga, mengharamkan yang halal dan sebaliknya merupakan kesyirikan. Sebuah hadits qudsi yang diriwayatkan Imam Muslim menyatakan, "Aku ciptakan hamba-hamba-Ku ini dengan sikeap yang lurus, tapi datanglab setan kepada mereka. Setan in kemudian membelokekan mereka dari agamanya dan mengharamkan atas mereka sesuatu yang Aku halalkan kepada mereka, serta mempengarubi mereka agar menyekutuan Ak.u dengan sesutau yang tidak. Aku turunkan keterangan kepadanya."

Keempat, mengaharapkan yang halal dan sebaliknya, berdampak pada timbulnya kejahatan dan bencana. Karena itulah, para ulama merumuskan kaidah yang berbunyi : Sesuatu yang bahayanya lebih besar adalah haram dan yang manfaatnya lebih besar adalah halal.

Kelima, setiap yang halal tidak memerlukan yang haram dan perantara menuju keharaman adalah haram. Allah tidak mengharamkan sesuatu kecuali ada substitusinya yang lebih baik dan memenuhi kebutuhan mansia. Sehingga manusia tidak perlu memanfaatkan yang haram dalam kehidupannya.

Keenam, bersiasat terhadap yang haram adalah haram. Sebagaimana sarana yang dihukumi haram jika digunakan untuk menuju keharaman, Islam pun mengharamkan segala siasat menuju keharaman.

Ketujuh, niat baik tidak menghalalkan yang haram. Amal shalih seorang muslim diterima sebagai ibadah bila dilandasi niat ikhlas dan dilakukan dengan cara yang syar'i. Satu saja unsur itu hilang, maka amal menjadi amal salah. Imam Muslim dan Tirmidzi meriwayatkan, Nabi Muhammad pernah berkata, "Sesunggubnya Allah itu baik, tidak menerima kecuali yang baik pula.Allah memerintah kepada m'min seperti halnya perintah kepada Rasul."

Kedelapan, perkara syubhat harus dijauhi agar tak terlibat haram. Ada sesuatu yang hukumnya berada di antara halal dan haram yaitu syubhat (remangremang). Hal ini terjadi karena tidak jelasnya dalil atau karena tidak jelasnya jalan untuk menganalogikan dengan hukum paralel. Mengenai hal ini, Islam 
menganjurkan kepada umatnya untk bersikap wara', yakni menjauhkan diri dari perkara syubhat agar tidak terseret pada yang haram.

Kesembilan, yang haram berlaku untuk semua orang. Keharaman satu zat tidak ditentukan dari sedikit banyaknya zat tersebut. Sesatu yang halal jika tercampur sesuatu yang haram maka akan dihukumi haram. Maka, logis bila persoalan halal dan haram berlaku mutlak untuk seluruh umat yang niscaya saling berinteraksi dalam kehidupannya.

Kesepuluh, darurat membolehkan yang haram. Dalam situasi darurat yang mengancam keselamatan nyawa seseorang diizinkan mengkonsumsi barang haram. Asalkan, tidak berlebihan atau seperlunya saja.

Penyembelihan adalah proses pemotongan dengan mengalirkan darah melalui pemotongan saluran makanan (mari'esophagus), saluran pernafasan/tenggorokan (bulqum/trachea), dan dua pembuluh darah (wadajain/vena jugularis dan arteri carotids).

Islam mengatur umatnya yang hendak mengonsumsi daging hewan untuk menyembelih terlebih dahulu hewan yang akan dikonsumsi. Karena daging hewan yang diambil dari hewan hidup adalah haram menurut syariat.

Di Indonesia petunjuk tentang penyembelihan yang halal telah diberikan oleh Majelis Ulama Indonesia (MUI) melalui fatwanya. Fatwa MUI Nomor 12 Tahun 2009 tentang Standar Penyembelihan Halal telah dikeluarkan pada tanggal 15 Dzulhijjah $1430 \mathrm{H}$ atau 2 Desember $2009 \mathrm{M}$.

Hal utama yang perlu diperhatikan adalah mengenai syarat dan rukun penyembelihan. Yusuf Al-Qardawi menyebutkan dalam kitabnya Halal Haram fil Islam mengenai syarat-syarat sembelih yang syar'i sebagai berikut.

a) Hewan tersebut harus disembelih atau ditusuk (nabr) dengan suatu alat yang tajam yang dapat mengalirkan darah dan mencabut nyawa hewan tersebut, baik alat itu berupa batu ataupun kayu.

b) Penyembelihan atau penusukan (nahr) itu harus dilakukan di leher hewan tersebut, yaitu: bahwa kematian hewan tersebut justru sebagai akibat dari terputusnya urat nadi atau kerongkongannya.

c) Tidak disebut nama selain Allah swt

d) Menyebut nama Allah swt (membaca basmallah).

Selain itu, MUI dalam fatwanya menetapkan bahwa standar hewan yang boleh disembelih adalah (1) Hewan yang disembelih adalah hewan yang boleh dimakan.; (2) Hewan harus dalam keadaan hidup ketika disembelih; (3) Kondisi hewan harus memenuhi standar kesehatan hewan yang ditetapkan oleh lembaga yang memiliki kewenangan. Standar penyembelih dalam fatwa MUI harus orang yang beragama Islam dan sudah aqil baligh, Memahami tata cara penyembelihan secara syar'i, dan memiliki keahlian dalam penyembelihan. MUI juga menyebut bahwa rukun penyembelihan adalah sebagai berikut.

a) Orang yang menyembelih (ذابح)

b) Hewan yang disembelih (ذذبح) 
c) Alat yang dipakai menyembelih (ألة)

d) Cara penyembelihan (ذبح)

Penyembilihan harus dilakukan dengan prinsip ASUH.

a) Aman : tidak mengandung bahaya biologis, kimiawi dan fisik atau bahanbahan yang dapat mengganggu kesehatan manusia

b) Sehat : mengandung bahan-bahan (nutrisi) yang dapat menyehatkan manusia (baik untuk kesehatan)

c) Utuh : tidak dikurangi atau dicampur dengan bahan lain

d) Halal : disembelih dan ditangani sesuai syariat agama Islam

Daging ASUH yang sesuai prinsip ASUH diantaranya adalah daging yang diperoleh dari ternak sehat, dipotong di rumah potong hewan/rumah potong umum (RPH/RPU) atau tempat potong hewan/tempat potong umum 9TPH/TPU) yang ditetapkan oleh Pemerintah, telah menjalani pemeriksaan ante- dan post-mortem oleh Dokter Hewan Berwenang atau Paramedik Veteriner di bawah pengawasan Dokter Hewan dan dinyatakan aman serta layak dikonsumsi manusia.

Disamping proses penyembelihan yang baik, hewan yang dipilih juga harus sesuai syariah. Pada prinsipnya semua hewan dihukumi boleh untuk disembelih kecuali yang telah diharamkan oleh syara'. Selain kebolehan atas hewan, kehalalan suatu hewan juga dipengaruhi oleh hal hal diluar hewan tersebut. Seperti, cara mendapatkan hewan, cara penyembelihan dal lain sebagainya.

Beberapa hewan yang halal untuk disembelih diantaranya hewan golongan mamalia. Diantara hewan dari golongan ini seperti sapi, kambing, unta. Sapi adalah hewan ternak anggota suku Bovidae dan anak suku Bovinae. Sapi dipelihara terutama untuk dimanfaatkan susu dan dagingnya sebagai pangan manusia. Hasil sampingan, seperti kulit, jeroan, tanduk, dan kotorannya juga dimanfaatkan untuk berbagai keperluan manusia. Di sejumlah tempat, sapi juga dipakai sebagai penggerak alat transportasi, pengolahan lahan tanam (bajak), dan alat industri lain (seperti peremas tebu). Karena banyak kegunaan ini, sapi telah menjadi bagian dari berbagai kebudayaan manusia sejak lama (https://id.wikipedia.org/wiki/Sapi).

Kambing merupakan anggota dari keluarga Bovidae dan bersaudara dengan dengan biri-biri karena keduanya tergolong dalam sub famili Caprinae. Terdapat lebih 300 jenis kambing yang berbeda-beda. Kambing adalah salah satu di antara spesies yang paling lama di ternakkan, yaitu untuk susu, daging, bulu, dan kulit di seluruh dunia. Kambing merupakan binatang memamah biak yang berukuran sedang. Kambing ternak (Capra aegagrus hircus) adalah sub spesies kambing liar yang secara alami tersebar di Asia Barat Daya (daerah "Bulan Sabit yang subur" dan Turki) dan Eropa. Kambing liar jantan maupun betina memiliki tanduk sepasang, namun tanduk pada kambing jantan lebih besar. Makanan utamanya adalah rumput-rumputan dan dedaunan. Kambing termasuk hewan yang halal untuk dikonsumsi. Syara' tidak melarang kambing. 
Unta atau Onta adalah dua spesies hewan berkuku belah dari genus Camelus (satu berpunuk tunggal - Camelus dromedarius, satu lagi berpunuk ganda - Camelus bactrianus) yang hidup ditemukan di wilayah kering dan gurun di Asia dan Afrika Utara. Rata-rata umur harapan hidup unta adalah antara 30 sampai 50 tahun. Pemanfaatan unta antara lain untuk diambil susu (yang memiliki nilai nutrisi lebih tinggi daripada susu sapi) serta dagingnya, dan juga digunakan sebagai hewan pekerja.

Selanjutnya hewan dari golongan Aves/burung, seperti ayam, bebek, burung dan lainnya. Ayam peliharaan (Gallus gallus domesticus) adalah unggas yang biasa dipelihara orang untuk dimanfaatkan untuk keperluan hidup pemeliharanya. Ayam peliharaan (selanjutnya disingkat "ayam" saja) merupakan keturunan langsung dari salah satu subspesies ayam hutan yang dikenal sebagai ayam hutan merah (Gallus gallus) atau ayam bangkiwa (bankiva fow'). Kawin silang antar ras ayam telah menghasilkan ratusan galur unggul atau galur murni dengan bermacam-macam fungsi; yang paling umum adalah ayam potong (untuk dipotong) dan ayam petelur (untuk diambil telurnya). Ayam biasa dapat pula dikawin silang dengan kerabat dekatnya, ayam hutan hijau, yang menghasilkan hibrida mandul yang jantannya dikenal sebagai ayam bekisar.

Dengan populasi lebih dari 24 milyar pada tahun 2003, Firefly's Bird Encyclopaedia menyatakan ada lebih banyak ayam di dunia ini daripada burung lainnya. Ayam memasok dua sumber protein dalam pangan: daging ayam dan telur.

Hal berikutnya yang penting dalam penyembelihan adalah alat yang dipakai untuk menyembelih. Sesuai fatwa MUI Nomor 12 tahun 2009 tentang Standar Penyembelihan Halal alat yang digunakan harus memenuhi syarat sebagai berikut:

a) Alat penyembelihan harus tajam

b) Alat yang digunakan bukanlah kuku, gigi/taring atau tulang.

Secara konkrit alat yang digunakan menyembelih berupa pisau. Pisau ialah alat yang digunakan untuk memotong sebuah benda. Pisau terdiri dari dua bagian utama, yaitu bilah pisau dan gagang atau pegangan pisau. Bilah pisau terbuat dari logam pipih yang tepinya dibuat tajam; tepi yang tajam ini disebut mata pisau. Pemilihan pisau haruslah tepat, karena akan mempengaruhi penyembelihan hewan. Jenis pisau yang biasanya digunakan untuk menyembelih hewan rumiansia adalah pisau curved boning dan skinning.

Standar proses penyembelihan juga telah dijelaskan oleh MUI dalam fatwanya sebagaimana di atas. Berikut standar prosesnya.

a. Penyembelihan dilaksanakan dengan niat menyembelih dan menyebut asma Allah.

b. Penyembelihan dilakukan dengan mengalirkan darah melalui Pemotongan saluran makanan (mari/esophagus), saluran Pernafasan/tenggorokan (bulqum/trachea), dan dua pembuluh darah (wadajain/vena jugularis dan arteri carotids). 
c. Penyembelihan dilakukan dengan satu kali dan secara cepat.

d. Memastikan adanya aliran darah dan/atau gerakan hewan sebagai tanda hidupnya hewan (hayah mustaqirrah).

e. Memastikan matinya hewan disebabkan oleh penyembelihan tersebut.

f. Dianjurkan badan binatang menghadap ke kiblat

g. Penyembelihan semaksimal mungkin dilaksanakan secara manual, tanpa didahului dengan stunning (membuat hewan pingsan) dan semacamnya.

Penyembelihan dengan stunning merupakan salah satu alat penyembelihan modern. Stunning adalah suatu cara melemahkan hewan melalui pemingsanan sebelum pelaksanaan penyembelihan agar pada waktu disembelih hewan tidak banyak bergerak. Hukumnya menurut al-Zuhaily (1998: 2800) boleh dengan syarat tidak menyakiti hewan dan tidak mematikan sebelum penyembelihan, (sesudah stunning statis hewan masih hidup).

a. Stunning hanya menyebabkan hewan pingsan sementara, tidak menyebabkan kematian serta tidak menyebabkan cedera permanen.

b. Bertujuan untuk mempermudah penyembelihan.

c. Pelaksanaannya sebagai bentuk ihsan, bukan untuk menyiksa hewan.

d. Peralatan stunning harus mampu menjamin terwujudnya syarat a, b, c serta tidak digunakan antara hewan halal dan non halal (misalnya, babi) sebagai langkah preventif.

e. Penetapan ketentuan stunning, pemilihan jenis, dan teknis pelaksanaannya harus dibawah pengawasan ahli yang menjamin terwujudnya syarat a, b, c dan d.

\section{PENGABDIAN PELATIHAN PENYEMBIHAN HALAL}

Kegiatan "Pelatihan Juru Sembelih Halal Berbasis Pada Walisongo Halal Research Center (WHRC)" didesain dalam bentuk pelatihan yang terdiri dari pemaparan teori dan praktek langsung. Dalam pemaparan teori tersebut disampaikan oleh tim dari LPPOM MUI Jawa tengah dan Walisongo Halal Research Center (WHRC).

Setelah peserta mendengarkan pemaparan teori penyembelihan, kemudian peserta diberi kesempatan untuk praktek penyembelihan secara langsung. Tahapan pelaksanaan dalam "Pelatihan Juru Sembelih Halal Berbasis Pada Walisongo Halal Research Center (WHRC)" diuraikan di bawah ini.

Pertama, tahap persiapan. Tahapan dilakukan dengan melakukan Koordinasi dengan Walisongo Halal Research Center (WHRC). Dalam kegiatan pelatihan juru sembelih halal ini memang mengacu pada standar yang ada dalam Walisongo Halal Research Center (WHRC), oleh karena itu sebelum pelaksanaan kegiatan terlebih dahulu melakukan koordinasi dengan pihak Walisongo Halal Research Center (WHRC). Adapun tujuan melakukan koordinasi dengan pihak Walisongo Halal Research Center (WHRC) adalah supaya kegiatan pelatihan juru sembelih halal dapat berjalan dengan baik dan terarah sesuai dengan visi/ tujuan dalam pelatihan ini. 
Setelah melakukan koordinasi secara intensif dengan pihak Walisongo Halal Research Center (WHRC), kami mendapatkan pencerahan dan pengarahan terkait program pelatihan juru sembelih halal Karya Pengabdian Dosen. Selain itu, kami juga disarankan untuk berkonsultasi dengan pihak LPPOM MUI Jawa Tengah dan DISNAKKESWAN Provinsi Jawa Tengah.

Upaya selanjutnya melakukan konsultasi dengan tutor ahli Penyembelihan. Setelah menerima informasi terkait pengumuman resmi penerima bantuan Karya Pengabdian Dosen (KPD) Individual LP2M UIN Walisongo pada 15 Mei 2017, kami selaku pelaksana pengabdian kemudian melakukan konsultasi dengan tutor ahli dalam bidang penyembelihan halal. Konsultasi dilakukan untuk membahas teknis pelatihan yang efektif dan efisien agar kegiatan pelatihan dapat tepat sasaran. Tutor ahli pelatihan juru sembelih halal yaitu dari LPPOM MUI Jawa tengah dan DISNAKKESWAN Provinsi Jawa Tengah.

Hasil dari konsultasi tersebut akhirnya pihak LPPOM MUI Jawa tengah dan DISNAKKESWAN Provinsi Jawa Tengah siap membantu dan mensukseskan dalam kegiatan pelatihan ini. LPPOM MUI Jawa Tengah siap mendampingi dan mengisi materi pelatihan efektif juru sembelih halal sesuai standar fatwa Majlis Ulama Indonesia (MUI).

Adapun pihak DISNAKKESWAN Provinsi Jawa Tengah mempersilakan kepada pengabdi untuk membantu dan mensukseskan kegiatan "Workshop Penanganan Hewan Qurban yang Aman, Sehat, Utuh, dan Halal" di UIN Walisongo Semarang pada tanggal 18 Agustus 20017. Kegiatan tersebut merupakan kerjasama pihak Walisongo Halal Research Center (WHRC) LP2M UIN Walisongo Semarang dengan DISNAKKESWAN Provinsi Jawa Tengah.

Langkah selanjutnya adalah melakukan sosialisasi kepada mahasiswa UIN Walisongo Semarang. Sosialisasi dilakukan selama bulan Juni 2017. Sosialisasi ini dilakukan guna menanamkan perspepsi mahasiswa terkait pentingnya penyembelihan hewan yang sesuai dengan Syara' (hukum islam), mengingat masih banyak ditemukan di beberapa tempat penyembelihan hewan yang tidak memperhatikan standar penyembelihan yang benar sesuai tuntutan agama islam.

Tujuan dari pelatihan juru sembelih halal ini yaitu memberi bekal kepada para calon alumni mahasiswa UIN Walisongo. Sehingga dengan diadakannya pelatihan ini para mahasiswa diharapkan mampu menerapkan dan menyebarluaskan ilmu juru sembelih halal yang profesional kepada masyarakat pada daerah asalnya masing-masing, mengingat mahasiswa UIN Walisongo berasal dari beberapa daerah. Selain itu menjadi juru sembelih halal juga dapat dijadikan sebagai wahana wirausaha yang profit, sehingga para mahasiswa nantinya tidak akan menjadi pengangguran setelah lulus.

Kedua, tahap pelaksanaan kegiatan. Pelaksanaan pelatihan juru sembelih halal dibagi dalam dua tahap yaitu pemaparan materi teknik juru sembelih halal dan praktek juru sembelih halal.

Dalam pemaparan materi teknik juru sembelih halal disampaikan oleh tenaga ahli dari LPPOM MUI Jawa Tengah. Sedangkan praktek juru sembelih 
halal dipandu langsung oleh pengabdi kegiatan "PelatihanJuruSembelih Halal berbasispadaW alisongo Halal Research Center (WHRC)" Karya Pengabdian Dosen (KPD) Individual ini.

Berikut ini adalah uraian tahapan dalam pelaksanaan kegiatan Karya Pengabdian Dosen (KPD) Individual yang berjudul "Pelatihan JuruSembelih Halal berbasis pada Walisongo Halal Research Center (WHRC)". Agenda diawali dengan Pemaparan Materi Teknik Juru Sembelih Halal. Pemaparan materi teknik juru sembelih halal disampaikan oleh pemateri dari LPPOM MUI Jawa Tengah yaitu Dr. H. Ahmad Izzuddin, M. Ag. (wakil direktur LPPOM MUI Jawa Tengah).

Dalam penyampaian materi tersebut dijelaskan secara jelas dan mendalam terkait tata cara penyembelihan hewan yang baik dan benar sesuai dengan syariat hukum islam. Pemateri juga menampilkan beberapa video terkait teknik penyembelihan hewan. Hal tersebut dilakukan guna memudahkan peserta pelatihan dalam memahami teknik penyembelihan. Adapun peserta pelatihan mendengarkan dengan seksama materi yang disampaikan.

Setelah pemateri menyampaikan materi tentang teknik penyembelihan halal, para peserta diberi kesempatan untuk bertanya dan berkomunikasi dengan pemateri. Sehingga antara pemateri dan peserta terjadi komunikasi yang interaktif.

Selanjutnya Praktek Juru Sembelih Halal. Praktek juru sembelih halal dipandu langsung oleh Drs. Mohamad Solek, MA. selaku penanggungjawab "PelatihanJuruSembelih Halal berbasispadaWalisongo Halal Research Center (WHRC)'.Dalam tahap ini, peserta pelatihan diberikan kesempatan untuk praktek menyembelih ayam. Hal tersebut dilakukan dengan tujuan agar peserta benar-benar dapat melakukan penyembelihan dengan baik dan benar sesuai syariat Islam. Sehingga dalam pelatihan ini seluruh peserta diharapkan mampu menjadi "Juru Sembelih Halal” di wilayah tempat tinggalnya masing-masing.

Tahapan proses penyembelihan halal berurutan sebagai berikut. Tahap Persiapan Penyembelihan. Pemeriksaan sebelum pemotongan meliputi pemeriksaan kesehatan ayam dengan cara mengamati kondisi fisik, suara, tingkah laku serta gejala klinis dari ayam. Hal ini untuk memastikan ayam yang akan dipotong, dagingnya layak dan aman untuk dikonsumsi.

Proses Penyembelihan. Pemotongan bertujuan untuk mematikan sekaligus mengeluarkan darah dari dalam tubuh ayam. Penyembelihan halal berdasarkan pada prinsip bahwa ayam sembelihan sedikit mungkin menderita dan darah harus keluar semaksimal mungkin. Hal ini dapat dilakukan dengan cara:

a) Penyembelihan ayam harus dilakukan oleh seorang muslim (beragama Islam), yang sehat jasmani dan rohani serta mempunyai kemampuan dalam bidang penyembelihan ayam.

b) Penyembelihan ayam harus menggunakan pisau yang tajam agar tidak menyiksa ayam yang akan disembelih 
c) Penyembelihan ayam disunatkan menghadap ke arah kiblat. Penyembelih berniat menyembelih dan menyebut nama Allah dengan membaca basmalah untuk setiap ekor ayam atau secara keseluruhan. Sebelum menyembelih disunatkan pula bertakbir sebanyak tiga kali

d) Penyembelihan ayam dilakukan dengan memotong ketiga urat yang terletak di leher, meliputi saluran makanan (esophagus), saluran pernapasan (trakea) dan pembuluh darah yang tebal di kanan kiri (vena jugularis dan arteri carotis) sampai putus sehingga darahnya dapat mengucur keluar sampai habis.

e) Selama proses pemotongan, diupayakan ayam tetap terjaga kebersihannya sehingga hasil pemotongan bersih dan sehat serta tidak mencemari lingkungan

Proses Pencabutan Bulu. Kegiatan ini diawali dengan mencelupkan tubuh ayam yang sudah disembelih ke dalam air panas bersuhu sekitar 55 - 60 derajat C selama 90 detik. Untuk ayam tua, pencelupan dilakukan lebih lama.

Selanjutnya dilakukan pencabutan bulu dimulai dari bagian mana saja dengan arah sesuai dengan pertumbuhan bulu. Bila pencabutan bulu berlawanan arahnya, maka akan menghasilkan kulit karkas sobek dan dapat menurunkan kualitas karkas.

Bila bulu kasar masih sulit dicabut perlu dilakukan pencelupan ulang selama beberapa detik. Pencelupan tidak boleh terlalu lama dan suhu air tidak boleh terlalu panas, karena dapat mengakibatkan perubahan warna (diskolorisasi) dan daging menjadi lembek.

Ketiga, tahap evaluasi. Setelah semua rangkaian tahap dijalani,maka langkah terakhir adalah melakukan evaluasi dan. Evaluasi ini perlu dilakukan supaya kegiatan ke depannya akan lebih baik. Kegiatan ini juga di desain supaya kedepannya dapat dilaksanakan secara berlanjut dengan dana swadaya.

Selain itu, pengawasan atau monitoring pasca kegiatan pelatihan juga penting untuk dilakukan. Pengawasan ini dilakukan dengan system koordinasi antara tutor ahli dan pelaksana pengabdian.

Pemantauan akan dilakukan selama 2-3 bulan. Hal-hal yang akan dipantau meliputi hasil pelaksanaan pelatihan juru sembelih halal, problem/ kendala pelatihan juru sembelih halal, dan rencana kegiatan setelah pelaksanaan pelatihan.

\section{CAPAIAN HASIL KINERJA PENGABDIAN}

Dalam pelaksanaan pengabdian masyarakat yang berbentuk "Pelatihan Juru Sembelih Halal berbasis pada Walisongo Halal Research Center (WHRC)”, tim pelaksana sudah bekerja ekstra untuk kesuksesan pengabdian ini. Sebelum pelaksanaan kegiatan dimulai, tim pengabdian jauh-jauh hari sudah mempersiapkan segala sesusatu yang dibutuhkan.

Tim pelaksana kegiatan beberapa kali melakukan koordinasi dengan tutor ahli guna mengemas kegiatan yang menarik dan berbobot. Kegiatan "Pelatihan Juru Sembelih Halal berbasis pada Walisongo Halal Research Center (WHRC)" 
disambut baik oleh para mahasiswa UIN Walisongo Semarang yang merupakan sasaran dari pelaksanaan pengabdian ini. Hal tersebut terlihat dari antusias dan keaktifan para mahasiswa untuk mengikuti pelatihan dengan baik.

Adapun capaian hasil kinerja pengabdian dalam pelaksanaan "Pelatihan Juru Sembelih Halal berbasis pada Walisongo Halal Research Center (WHRC)”, yaitu:

1. Mahasiswa mampu memahami cara menyembelih yang halal (sesuai Syara' dan Standar MUI).

2. Mahasiswa mampu mempraktekkan menjadi juru sembelih yang halal.

Dengan adanya pelatihan tersebut, para mahasiswa UIN Walisongo Semarang mendapatkan sertifikat "Juru Sembelib Halal". Sehingga nantinya setelah mahasiswa wisuda/ lulus dari perguruan tinggi UIN Walisongo Semarang dapat menjadikan bekal di dunia nyata dengan harapan dapat membuka lapangan pekerjaan yang baru dan tidak menjadi pengangguran.

Meskipun demikian, kegiatan "Pelatiban Juru Sembelib Halal berbasis pada Walisongo Halal Research Center (WHRC)", sebenarnya sudah dipersiapkan dengan maksimal dengan desain kegiatan yang baik dan menarik, namun masih saja terdapat hambatan atau kendala, diantaranya yaitu:

1. Belum adanya RPH (Rumah Penyembelihan Hewan) di UIN Walisongo.

2. Keterbatasan sarana dan prasarana.

3. Banyaknya minat mahasiswa mengikuti pelatihan juru sembelih halal namun keterbatasan anggaran dan sarana prasarana penunjang pelatihan.

Dengan adanya hambatan-hambatan tersebut tidak menjadikan kendala bagi tim pelaksana pengabdian. Hal tersebut justru menjadikan pemicu untuk membuat rencana kegiatan (setelah pelaksanaan pelatihan), yaitu:

1. Mahasiswa/alumni UIN Walisongo Semarang ditempatkan sebagai “JuruSembelih Halal yang Profesional” di daerah asalnya masing-masing.

2. Mahasiswa/alumni UIN Walisongo diarahkan untuk membantu mendistribusikan daging yg halal (penyembelihan sesuai syara') dengan bekerja sama kepada RPH (Rumah Potong Hewan) Kota Semarang.

\section{KESIMPULAN}

Uraian di atas memberikan simpulan berupa, 1) Penyembelihan adalah proses pemotongan dengan mengalirkan darah melalui pemotongan saluran makanan (mari'/ esophagus), saluran pernafasan/ tenggorokan (bulqum/ trachea), dan dua pembuluh darah (wadajain/ vena jugularis dan arteri carotids). 2) Dalam Fatwa MUI Nomor 12 tahun 2009 tentang Standar Penyembelihan Halal dijelaskan bahwa standar hewan yang boleh disembelih adalah (1) Hewan yang disembelih adalah hewan yang boleh dimakan.; (2) Hewan harus dalam keadaan hidup ketika disembelih; (3) Kondisi hewan harus memenuhi standar kesehatan hewan yang ditetapkan oleh lembaga yang memiliki kewenangan. 3) Daging yang ASUH adalah daging yang memiliki kriteria Aman (tidak mengandung bahaya biologik, kimia dan fisik yang dapat menyebabkan penyakit serta mengganggu kesehatan manusia), Sehat (memiliki zat-zat yang dibutuhkan 
dan berguna bagi kesehatan dan pertumbuhan tubuh), Utuh (tidak dicampur dengan bagian lain dari hewan tersebut atau bagian dari hewan lain), Halal (dipotong dan di tangani sesuai dengan syariat agama Islam). 4) Capaian hasil kinerja pengabdian dalam pelaksanaan "PelatihanjuruSembelih Halal berbasis pada Walisongo Halal Research Center (WHRC)", yaitu: Mahasiswa mampumemahami cara menyembelih yang halal (sesuai Syara' dan Standar MUI) dan mampu berpraktek menjadi jurusembelih yang halal.

\section{Rekomendasi}

Dari pelaksanaan pengabdian berjudul "Pelatihan Juru Sembelih Halal berbasis pada Walisongo Halal Research Center (WHRC)" tersebut, berikut ini ditawarkan beberapa rekomendasi sebagai solusi guna perbaikan kegiatan yang akan datang, diantaranya yaitu:

1. Mendirikan atau membuat RPH (Rumah Penyembelihan Hewan) di UIN Walisongo.

2. Menyediakan sarana dan prasarana sebelum pelaksanaan kegiatan.

3. Memberikan sosialisasi yang mendalam kepada mahasiswa UIN Walisongo Semarang terkait manfaat dan pentingnya penyembelihan hewan yang halal. 


\section{DAFTAR PUSTAKA}

Blakely, J. dan D.H. Bade. 1992. Ilmu peternakan diterjemahkan oleh Bambang Srigandono. Gadjah Mada University Press : Yogyakarta.

Departemen Agama, Petunjuk Teknis Pedoman Sistem Produksi Halal, Jakarta: DirektoratJenderalBimbinganMasyarakatislamdanPenyelenggaraan Haji Departemen Agama, 2003.

Imam al-Syawkânî, Fathal-Qâdir.

Jalaluddin Abd. Al-Rahman, Ghayah al-Wusul ila Daqaiq Ilm alUshul, Matba'ah al-Sa'adah, T.t., 1979.

Kemenag RI, Petunjuk Teknis Pedoman Sistem Produksi Halal.

Muchtar Ali, Konsep Makanan Halal Dalam Tinjauan Syariah Dan Tanggung Jawab Produk. Atas Produsen Industri Halal, Jurnal Ahkam.

Muchtar Ali, Konsep Makanan Halal Dalam Tinjauan SyariabDan Tanggung Jawab Produk Atas Produsen Industri Halal, Jurnal Ahkam.

Muhammad Rawas Qal'ajî dan Muhammad Shâdiq Qanaybî, Mu'jam Lughah al-Fuqahâ, (Bayrût: Dâr al-Fikr, 1405H-1985M), Cet. I.

Parry, R. T. 1989. Technological Development in Pre-Slaughter Handling and Processing in Processing of Poultry. Mead, G. C. Elsevier Applied Science. England.

PedomanProduksidanPenangananDagingAyam yang Higenis, Jakarta: KementerianPertanian, 2010.

Soeparno. 1992. Ilmu dan Teknologi Daging. Cetakan ke-1. Gadjah Mada University Press. Yogyakarta.

Undang, S. 1995. Tatalaksana pemeliharaan ternaksapi. Penebar Swadaya Jakarta.

Veerkamp, C. H. 1989. Chilling, Freezing and Thawing in Processing of Poultry. Mead, G. C. Elsevier Applied Science. England. 
Wahbah Al-zuhaily, Al- Fiqh Al- Islamy Wa Adillatuh, juz 4.

https://id.wikipedia.org/wiki/Haram,diakses pada tanggal 27 September 2017 pukul 20.00 WIB.

https://id.wikipedia.org/wiki/Sapi, diaksespadatanggal30 September 2017 pukul 20.39 WIB. 